\title{
Pemberdayaan ekonomi masyarakat pelaku usaha UMKM di Kelurahan Limbungan Kecamatan Rumbai Pesisir Kota Pekanbaru
}

\author{
Sri Endang Kornita*, Syafril Basri, Restu, Ufira Isbah, \& Selly Prima Desweni \\ Universitas Riau \\ *sri.endangkornita@lecturer.unri.ac.id
}

\begin{abstract}
Abstrak. Kegiatan pengabdian yang dilakukan adalah Pemberdayaan Ekonomi Masyarakat Pelaku UMKM di Kelurahan Limbungan Kecamatan Rumbai Pesisir Kota Pekanbaru. Adapun kegiatan ini terintegrasi dengan pelaksanaan Kukerta UNRI tahun 2020. Peran tim pengabdian dalam pemberdayaan ekonomi masyarakat pelaku UMKM berupa pelatihan pengelolaan usaha (manajemen keuangan; perpajakan), strategi pengembangan usaha serta pendampingan bagi pelaku UMKM yang diikuti 19 pelaku UMKM (pengelola atau pemilik) di daerah ini. Kegiatan pengabdian ini bertujuan untuk meningkatkan pemahaman dan implementasi pengelolaan UMKM secara profesional, efisien, dan efektif, sehingga dapat mewujudkan kemandirian serta kesejahteraan bagi masyarakat guna mengoptimalkan potensi yang ada. Hal ini juga diharapkan mampu memberikan suatu nilai tambah bagi masyarakat, terutama dalam kegiatan ekonomi yakni dapat meningkatkan kesejahteraan masyarakat dari berkembangnya usaha yang mereka lakukan. Dari kegiatan pelatihan ini juga dapat merubah perilaku masyarakat menjadi masyarakat yang lebih kreatif dan mendorong peningkatan pendapatan masyarakat pada lokasi pengabdian. Metode pelatihan berupa perpaduan antara ceramah bervariasi dan pendampingan, dimana dalam pelatihan peserta memperoleh buku panduan materi tentang keuangan dan perpajakan UMKM. Dari hasil kegiatan terlihat peserta lebih memahami dan mengerti tentang pembukuan dan keuangan UMKM, perpajakan, dan pemasaran secara online setelah mengikuti kegiatan pengabdian dan kukerta terintegrasi LPPM UNRI.
\end{abstract}

Kata kunci: pemberdayaan, ekonomi, UMKM

\begin{abstract}
The community service activities carried out are Community Economic Empowerment of MSME Entrepreneurs in Limbungan Village, Rumbai Pesisir District, Pekanbaru City. This activity integrated with the implementation of the Student Community Service Program of 2020. The role of the community service team is business management training (financial management, taxation), strategy of business development, and accompaniment for the 19 MSME entrepreneurs in this area that participated. The aims of this community service activity are to improve understanding and implementation of MSME management in a professional, efficient, and effective way, with the result that can manifest independence and well-being of the community to optimize the existing potential. It is also expected that this training will provide an added value for the community development of MSME entrepreneurs's business. This training can change community behavior into more creative and improve community income in this area. The training methods are a combination between lectures and accompaniment, where participants will obtain material manual books about finance and taxation of MSME. It can be seen that the participants have more understanding about bookkeeping and finance of MSME, taxation, and online marketing after participating in the integrated community service and student community service program of LPPM UNRI.
\end{abstract}

Keywords: empowerment, economy, MSME

To cite this article: Kornita, S. E., S. Basri., Restu., U. Isbah., S. P. Desweni. 2020. Pemberdayaan ekonomi masyarakat pelaku usaha UMKM di Kelurahan Limbungan Kecamatan Rumbai Pesisir Kota Pekanbaru. Unri Conference Series: Community Engagement 2: 494-497. https://doi.org/10.31258/unricsce.2.494-497

(C) 2020 Authors

Peer-review under responsibility of the organizing committee of Seminar Nasional Pemberdayaan Masyarakat 2020 


\section{PENDAHULUAN}

UMKM mempunyai peran yang sangat besar dalam memajukan perekonomian Indonesia dimana UMKM berkontribusi besar dalam penyerapan tenaga kerja, yaitu menyerap lebih dari 99,45\% tenaga kerja dan sumbangan terhadap PDB sekitar 30\%, selain itu UMKM juga menyerap banyak tenaga kerja Indonesia yang masih menganggur (Susila dan Supartomo; dalam Bahri dan Prasetyo, 2020). Permasalahan yang dihadapi oleh sektor Usaha Mikro Kecil dan Menengah, terutama sektor industri pengolahan secara umum, saat ini adalah (a) rendahnya kualitas sumber daya manusia dalam bidang teknologi informasi dan perencanaan usaha; (b) terbatasnya kemampuan permodalan usaha Industri kecil dan menengah; (c) belum optimalnya peran sistem pendukung bagi perkembangan usaha Industri kecil dan menengah oleh pemerintah daerah, dan (d) kebijakan dan peraturan pemerintah yang kurang mendukung/kurang berpihak pada perkembangan dan kemajuan sektor Usaha Mikro Kecil dan Menengah, sektor industri pengolahan. UMKM sendiri adalah suatu badan usaha yang merupakan salah satu wadah dan wahana yang sesuai bagi pelaksanaan pembangunan nasional dibidang perekonomian terutama dalam bidang usaha peningkatan kemampuan yang lebih besar bagi golongan ekonomi lemah untuk berpartisipasi dalam proses pembangunan. Hal ini bagi pengelola UMKM merupakan peran dan fungsi dalam membangun dan mengembangkan potensi dan kemampuan ekonomi masyarakat untuk meningkatkan kesejahteraan ekonomi dan sosialnya serta mempertinggi kualitas hidupnya (Kartasasmita, 2003).

Permasalahan sumber daya manusia sektor Usaha Mikro Kecil dan Menengah sektor industri pengolahan pada umumnya disebabkan oleh rendahnya pendidikan, keterampilan dan pengalaman, serta akses ke informasi yang masih sangat terbatas. Sebagian besar pelaku Usaha Mikro Kecil dan Menengah juga belum memiliki kapasitas kewirausahaan yang memadai. Hal ini tampak dari pola bisnis Usaha Mikro Kecil dan Menengah yang masih banyak difokuskan atau hanya berorientasi pada jumlah produksi, bukan pada kualitas produksi dan permintaan pasar (selera konsumen). Sementara itu kurang optimalnya peran sistem pendukung telah meningkatkan kompleksitas dalam akses Usaha Mikro Kecil dan Menengah sektor industri pengolahan terhadap sumber daya (bahan baku dan pembiayaan), teknologi dan pemasaran. Sistem pendukung usaha tersebut dapat mencakup lembaga penyedia/pemasok bahan baku, lembaga pembiayaan, lembaga litbang, mediator pemasaran, Lembaga Pelayanan Bisnis/LPB, dan lembaga lain yang terkait. Peran sistem pendukung sektor usaha Mikro Kecil dan Menengah juga tidak terlepas dari ketersediaan infrastruktur serta insentif. Hal ini juga terjadi di berbagai daerah di Provinsi Riau (Kornita, 2011). Untuk itu diperlukan Program pengembangan UMKM merupakan kebijakan penengembangan bisnis untuk diimplementasikan oleh berbagai pihak yang berkepentingan. Program ini berorientasi pada kebutuhan nyata UMKM dengan memprioritaskan pada peningkatan efisiensi dan daya saing sehingga pada akhirnya mampu meningkatkan penyerapan tenaga kerja dan memberi nilai tambah (value added) (Hardi dan Zaharman, 2018).

Covin dan Slevin (1991) menjelaskan bahwa konsep dari entrepreneurship dijabarkan pada tingkatan organisasional yang disebut dengan orientasi kewirausahaan. Orientasi kewirausahaan didefinisikan sebagai proses, struktur dan perilaku perusahaan yang memiliki karakteristik dari inovatif, proaktif dan berani mengambil resiko. Sementara itu, pengusahaan atau pengelolaan usaha yang dilakukan oleh pelaku usaha UMKM di Kota Pekanbaru yang ditemui pada sebagian besar pelaku usaha UMKM adalah rendahnya pemahaman terhadap manajemen usaha, hal ini dikarenakan pelaku usaha hanya melakukan usaha untuk mendapatkan pendapatan saja tanpa memikirkan upaya untuk meningkatkan usahanya. Melakukan analisis terhadap kondisi keuangan usaha UMKM juga merupakan salah satu bagian dari manajemen usaha, karena kondisi dari keuangan merupakan indikator kinerja dari keberhasilan usaha UMKM yang dilakukan. Berdasarkan hasil observasi awal ditemukan beberapa permasalahan yang berhubungan dengan keuangan pada pelaku usaha UMKM. Permasalahan keuangan yang dihadapi antara lain adalah kemampuan pengelolaan dana yang berputar untuk menghasilkan keuntungan masih rendah, dan pengetahuan tentang pengelolaan keuangan serta perpajakan belum dikuasai oleh pelaku UMKM.

Berdasarkan hal tersebut, maka dirasa perlu adanya kegiatan pengabdian berupa penyuluhan dan pembinaan, dalam rangka meningkatkan kualitas sumberdaya atau khususnya pengusaha UMKM di Kelurahan Limbungan Kecamatan Rumbai Pesisir, Kota Pekanbaru dengan fokus memberikan solusi bagi permasalahan keuangan atau khususnya tentang manajemen keuangan, serta mendiskusikan strategi yang mungkin dilakukan untuk mengatasi masalah keuangan. Sehingga pada tahap selanjutnya pelaku usaha UMKM akan lebih mampu mengembangkan usahanya secara lebih profesional, efisien dan efektif bagi peningkatan kesejahteraan masyarakat. 


\section{METODE PENERAPAN}

Metode penerapan yang digunakan dalam kegiatan pengabdian ini adalah:

a. Penyampaian materi dengan cara memberikan ceramah, tanya jawab dan diskusi tentang bagaimana membuat dan menyusun laporan keuangan dan pajak bagi usaha UMKM yang dijalankan, strategi yang dilakukan dalam pengembangan usaha, mendiskusikan permasalahan dan solusinya yang dihadapi oleh para pelaku usaha UMKM di Kelurahan Limbungan Kecamatan Rumbai Pesisir Kota Pekanbaru. Materi tertulis akan dibagikan kepada semua peserta.

b. Memberikan contoh-contoh strategi sesuai dengan kegiatan usaha yang dilakukan.

c. Pengembangan kemampuan pelaku UMKM dalam manajemen keuangan, perpajakan dan strategi usahanya dengan praktek langsung.

Tabel 1. Pelaksanaan Kegiatan Pengabdian

\begin{tabular}{|c|c|c|c|}
\hline DESA/ KECAMATAN & KEGIATAN & WAKTU & PELAKSANA \\
\hline \multirow{12}{*}{$\begin{array}{c}\text { Kelurahan Limbungan } \\
\text { Kecamatan Rumbai Pesisir } \\
\text { Kota Pekanbaru }\end{array}$} & Penyampaian Materi & \multirow[t]{5}{*}{ Juli 2020} & 1. Dr. Sri Endang Kornita, SE., M.Si \\
\hline & Manajemen Pengelolaan & & 2. Drs. H. Syafril Basri, M.Si \\
\hline & Keuangan UMKM & & 3. Drs. H. Restu, M.Si \\
\hline & Penyampaian Materi Perpajakan & & 4. Ufira Isbah, SE., MSc \\
\hline & Pemasaran online & & 5. Selly Pria Desweni, SE., ME \\
\hline & \multirow{7}{*}{ Pendampingan UMKM } & \multirow{7}{*}{$\begin{array}{c}14 \text { Kali } \\
\text { Pertemuan }\end{array}$} & 1.Dr. Sri Endang Kornita, SE., M.Si \\
\hline & & & 2. Drs. H. Syafril Basri, M.Si \\
\hline & & & 3. Drs. H. Restu, M.Si \\
\hline & & & 4. Ufira Isbah, SE., MSc \\
\hline & & & 5. Selly Pria Desweni, SE., ME \\
\hline & & & 6.Mahasiswa KukertaTerintegrasi \\
\hline & & & Unri, Tahun 2020 \\
\hline
\end{tabular}

\section{HASIL DAN KETERCAPAIAN SASARAN}

Pengabdian kepada masyarakat pelaku UMKM di Kelurahan Limbungan berupa Pelatihan dan Penyuluhan, serta Pendampingan terkait pelaku UMKM dilaksanakan terhadap 19 (Sembilan belas) orang pelaku usaha. Kegiatan ini melibatkan 9 (Sembilan) orang mahasiswa Kukerta Terintegrasi Unri Tahun 2020 yang berada di Kelurahan Limbungan, Kecamatan Rumbai Pesisir Kota Pekanbaru. Masyarakat Pelaku Usaha UMKM di Kelurahan Limbungan, Kecamatan Kecamatan Rumbai Pesisir memiliki potensi untuk di kembangkan, melalui pelaksanaan pengabdian ini dapat diketahui potensi usaha UMKM yang beragam dan usaha rumah tangga yang memiliki peluang untuk berkembang lebih baik. Disamping itu, dukung an dari pemerintah pada level Kelurahan, Kecamatan, dan Kota Pekanbaru terhadap upaya pengembangan UMKM di daerah ini memberi iklim yang kondusif bagi pelaku usaha. Potensi kedepan akan lebih baik bila dilakukan pendampingan secara berkelanjutan baik oleh pemerintah maupun melalui pengabdian masyarakat perguruan tinggi yang ada. Ketercapaian sasaran dari kegiatan pelatihan ini dapat dinyatakan 100\%, karena kegiatan yang dilakukan sesuai rencana dapat terlaksana semua dan didukung tambahan materi bagi pemberdayaan pelaku UMKM dalam pemasaran online yang dilaksanakan mahasiswa kukerta terintegrasi sebagai bentuk kegiatan pendukung pemberdayaan UMKM pada lokasi sasaran.

\section{KESIMPULAN}

Sebagai kesimpulan dari kegiatan Pengabdian masyarakat ini, maka dapat disampaikan hal-hal sebagai berikut: a. Pelaku usaha UMKM di Kelurahan Limbungan memerlukan Pembukuan atau Keuangan UMKM agar dapat menjalankan usaha dengan lebih professional.

b. Pelaku usaha UMKM di Kelurahan Limbungan memerlukan Pengetahuan Perpajakan UMKM agar dapat menjalankan usaha dengan lebih professional.

c. Pelaku usaha UMKM di Kelurahan Limbungan sebagian besar $(75 \%)$ belum menggunakan pemasaran secara online. Maka pengetahuan pemasaran online juga penting dimiliki terutama pada masa pandemic Covid-19 ini. 
d. Bagi keberlanjutan kedepan, maka perlu pendampingan perlu dilakukan secara berkesinambungan; peningkatan peran pemerintah dalam membina Pelaku usaha UMKM di Kelurahan Limbungan; serta masih dibutuhkan aktivitas pengabdian masyarakat dan tri dharma perguruan tinggi dengan berbagai potensi yang dimiliki melalui sinergy dengan perguruan tinggi.

\section{DAFTAR PUSTAKA}

Bahri dan Prasetyo, Widodo. 2020. Pengentasan kemiskinan melalui pemberdayaan wirausaha dan program life skill untuk meningkatkan produktivitas kelompok UPPKS Kalipakem Baru. Riau Journal of Empowerment, 3(1), $27-$ 37. https://doi.org/10.31258/raje.3.1.27-37

Covin, J. G., \& Slevin, D. P. 1991. A Conceptual Model of Entrepreneurship as Firm Behavior. Entrepreneurship Theory and Practice, 16(Fall), 7-26.

Hardi dan Zuharman. 2018. Strategi Pemerintah Kota Pekanbaru Dalam Pemberdayaan Dan Pembinaan UMKM Menghadapi MEA. Jurnal Daya Saing, 4(1).

Kornita, Sri Endang. 2011. Studi Kelayakan UMKM di Kabupaten Bengkalis. Penelitian kerjasama Dinas Koperasi dan UKM Kabupaten Bengkalis.

Kartasasmita, Ginandjar. 2003. Pemberdayaan Masyarakat: Konsep pembangunan yang berakar pada masyarakat. Jakarta 